\title{
Kielen matka puheesta kirjoitukseen - miten ja miksi
}

Liisa Tiittula \& Pirkko Nuolijärvi (toim.): Puheesta tekstiksi. Puheen kirjallisen esittämisen alueita, keinoja ja rajoja. Suomalaisen Kirjallisuuden Seuran toimituksia 1424. Helsinki: Suomalaisen Kirjallisuuden Seura 2016. 286 s. ISBN 978-952-222-735-5.

Puhuttu ja kirjoitettu kieli ovat erilaisia. Tämä kahtiajako on monelle itsestäänselvyys, ja se heijastuu stereotyyppisiin käsityksiin puhekielen ja kirjakielen erillisistä, tarkkaan rajatuista käyttöyhteyksistä. Mutta kuten kieleen liittyvissä ilmiöissä yleensä, todellisuus on tässäkin monisyisempi. Vaikka puhuttu ja kirjoitettu kieli hyödyntävät erilaisia semioottisia kanavia, ne elävät usein myös rinnakkain ja limittäin: Tekstit kaikuvat puheissa, ja puhetta siirretään teksteiksi. Julkista puhetta kirjoitetaan ja korjaillaan yleensä useaan kertaan ennen sen esittämistä, kun taas keskustelupalstalle tai kännykkään lähetetty kirjoitus voi olla hyvinkin spontaanisti tuotettu ja viimeistelemätön. Tällaisissa puhutun ja kirjoitetun kielen leikkauspisteissä kielimuotojen tarkka kahtiajako hämärtyy ja esiin nousee semioottisen kanavan lisäksi monia muita tekijöitä, jotka vaikuttavat ihmisten tapoihin käyttää kieltä.

Liisa Tiittulan ja Pirkko Nuolijärven toimittamassa teoksessa tarkastellaan yhtä puhutun ja kirjoitetun kielen leikkauspistettä: niitä tilanteita, joissa puhetta siirretään kirjoitettuun muotoon. Puheesta tekstiksi: Puheen kirjallisen esittämisen alueita, keinoja ja rajoja esitte- lee teoreettisen pohjustuksen jälkeen seitsemän lähestymistapaa aiheeseen. Onnistuneesti tutkimusta ja omakohtaista ammattikokemusta eri tavoin yhdistelevät artikkelit esittelevät toimintatapoja, joilla eri alojen toimijat siirtävät spontaania puhetta tekstiksi. Kokoelmassa on valaisevia artikkeleita journalistien, tutkijoiden, kirjailijoiden ja kirjallisuuden kääntäjien, ohjelmatekstittäjien ja kirjoitustulkkien työstä sekä sitä ohjaavista tavoitteista. Teoksessa tarkastellaan myös eduskunnan pöytäkirjatoimiston toimintaa sekä automaattisia puheentunnistimia, joilla on sekä samanlaisia että erilaisia haasteita puheen käsittelemisessä kuin ihmisillä. Teos etenee teoriaan ja tutkimuksen tekemiseen painottuvista artikkeleista yksittäisistä aloista kertoviin teksteihin.

\section{Kuka siirtää puhetta tekstiksi, miten ja miksi}

Artikkeleissa esitellään paitsi eri aloilla eriasteisesti vakiintuneita käytäntöjä myös niitä yhteiskunnallisia tarkoitusperiä, joita varten puhetta esitetään tekstimuodossa. Johanna Ruusuvuori ja Pirjo Nikander tarkastelevat asiaa tutkimuksen teon kannalta artikkelissaan "Puheen litterointikäytännöistä eri tutkimustarkoituksiin". He esittelevät haastattelussa tai spontaanissa vuorovaikutuksessa tuotetun puheen litterointitapoja laadullisessa sisällönanalyysissa, diskurssianalyysissa ja keskustelunanalyysissa. Artikkeli on tiivis ja havainnollinen johdanto puhetta sisäl- 
tävien aineistojen tutkimukseen. Se herättää myös pohtimaan litterointikäytäntöihin liittyvien valintojen analyyttisia ja eettisiä seurauksia. Koska litterointi on kielen ja yhteiskunnan tutkijan perustyökalu ja pohjustaa implisiittisesti monia muita teoksen artikkeleita, olisi aiheesta lukenut mielellään pidemmältikin. Artikkelissa havainnollistetaan onnistuneesti, kuinka tutkimusasetelma ja tutkittava ilmiö määrittävät, mitä elementtejä litteraattiin on tarpeen sisällyttää. Esimerkiksi keskustelunanalyyttiseen litteraattiin on yleensä tarpeen merkitä äänenvoimakkuuden muutoksia ja hengityksiä, koska ne voivat ilmaista vaikkapa tunnetiloja. Sisällönanalyysissa tällainen puheen aines sen sijaan ei yleensä ole tarpeellista.

Tutkimustarkoituksiin tehty litteraatti pyrkii minimoimaan kielenkäytön kanavan vaihtumisesta aiheutuvat muutokset, mutta monella muulla alalla erot spontaanin puheen ja siitä tehdyn kirjallisen esityksen välillä voivat olla huomattavia. Hyvän esimerkin tarjoaa Eero Voutilaisen artikkeli "Tekstilajitietoista kielenhuoltoa: Puheen esittäminen kirjoitettuna eduskunnan täysistuntopöytäkirjoissa”. Läpinäkyvän parlamentarismin nimissä on tärkeää, että kansalaiset ja esimerkiksi journalistit pääsevät lukemaan, mitä ja miten kansanedustajat puhuvat eduskunnan täysistunnoissa. Pöytäkirjatoimiston periaatteena kuitenkin on, että useimmat lapsukset korjataan ja takeltelut jätetään pois, elleivät keskustelun osallistujat itse kiinnitä niihin huomiota. Etenkin epäröinnit ja täyteäänet jätetään lähes aina pois, koska kirjoitettuina ne saattaisivat häiritä ja antaa puhujasta korostuneen epävarman kuvan (s. 18o, 182). Voutilainen nimittää tätä tekstilajilähtöiseksi kielenhuolloksi. Kuten kirjoittaja toteaa (s. 183), joskus on kuitenkin hankala erottaa harmitonta lapsusta puhujan tietämättömyydestä. Jos on selvää, että kyse on jälkimmäisestä, virhe kirjataan pyötäkirjaan sellaisenaan. Kyse on kuitenkin melko uu- desta käytänteestä, sillä vielä 1980-luvulla pöytäkirjoista tehtiin täysin asiavirheettömiä (s. 186-187).

Tulevaisuudessa automaattinen puheentunnistus tulee odotettavasti entistä suuremmaksi osaksi monen kieliammattilaisen työtä. Puheentunnistuksen haasteista ja mahdollisuuksista kirjoittaa Mikko Kurimo artikkelissaan "Puheentunnistuksen toimintaperiaatteet ja hyödyntämismahdollisuudet tekstityksessä ja kirjoitustulkkauksessa". Kirjoittajan mukaan puheentunnistusohjelmilta odotetaan helposti suuria, koska ihmisille puheen tunnistaminen ja erottaminen muusta äänestä on niin luonnollista ja vaivatonta. Kokonaisuudessaan $\mathrm{Ku}$ rimon artikkeli on ajankohtainen ja sopii teokseen hyvin. Käsittelyä olisi voinut kuitenkin tukea havainnollistuksin, jotta aiheeseen entuudestaan perehtymätön humanistikin olisi päässyt paremmin perille ohjelmien toimintaperiaatteista ja nähnyt, millaista tekstiä ne tuottavat spontaanista puheesta. Lisäksi artikkelin otsikossa luvattua puheentunnistuksen hyödyntämismahdollisuuksia tekstityksessä ja kirjoitustulkkauksessa ei juuri käsitellä.

Monet artikkeleissa esitetyistä puheeseen tehdyistä muutoksista juontuvat osittain siitä, että puhe ja kirjoitus eivät ole semioottisina kanavina yhteismitallisia. Toisaalta, kuten monissa teoksen artikkeleissa todetaan, osa muutoksista ei johdu pelkästään kanavan vaihtumisesta vaan myös lukuisista tilannesidonnaisista tekijöistä, esimerkiksi tekstin tarkoituksesta. Päivi Rainòn ja Sirpa Laurénin artikkeli "Kirjoitustulkkaus - puheen litterointia vai kielensisäistä tulkkausta?" kartoittaa näitä tilannesidonnaisia tekijöitä kirjoitustulkkauksen näkökulmasta. Kirjoitustulkkaus on saavutettavuuspalvelu, jonka käyttäjiä ovat kuulonsa menettäneet henkilöt, jotka eivät kommunikoi ensisijaisesti viittomakielellä. Kirjoitustulkki kirjoittaa keskusteluja, puheen- 
vuoroja ja ympäristön äänimaisemaa useimmiten digitaaliselle näytölle asiakkaan luettavaksi. Artikkelissa esitellään kattavasti ja kunnianhimoisesti kirjoitustulkkien työn konteksteja ja apuvälineitä sekä asiakaskokemusta. Tekstissä käsitellään myös kirjoitustulkkauksen historiallista kehitystä ja yhteyksiä litterointiin ja tulkkaukseen. Kirjoittajat soveltavat kirjoitustulkkaukseen myös Bronfenbrennerin (esim. 2005 [2001]) bioekologista systeemiteoreettista mallia, jonka avulla he kartoittavat kirjoitustulkkauksen toimijoita ja konteksteja ja niiden kronologista muutosta. Vaikka esitys on moniaalle haarova ja sen vuoksi paikoin hieman pinnallinen, kirjoittajat osoittavat vakuuttavasti, kuinka monet tekijät kirjoitustulkkaukseen vaikuttavat.

Toiseen saavutettavuuspalveluun keskittyy Minna Pöntyksen artikkeli "Ohjelmatekstitys - silmin nähtävää puhetta". Siinä tarkastellaan useimmille suomalaisille tutumman käännöstekstityksen sisarlajia, jossa suomenkielisten televisiolähetysten puhetta ja äänimaisemaa tekstitetään ääntä kuulemattomalle yleisölle. Ohjelmatekstityksen kohderyhmänä ovat siis ensisijaisesti kuurot ja huonokuuloiset, mutta sen käyttäjiä ovat myös esimerkiksi kielenoppijat tai sellaiset katsojat, jotka pitävät television äänen hiljaisella esimerkiksi julkisissa tiloissa tai muiden perheenjäsenten mentyä nukkumaan. Pöntys, jolla on pitkä kokemus Ylen ohjelmatekstityksestä sekä tekstitysten laatijana että tekstitystyön esimiehenä, tarkastelee artikkelissaan ohjelmatekstityksen käytäntöjä ja haasteita kahden Ylen ohjelmistosta otetun esimerkin avulla. Pöntys toteaa, että ohjelmatekstityksiin vaikuttavat ruututeksteille ominaiset rajoitteet, kuten tila ja lukuaika, mutta ennen muuta pyrkimys välittää ohjelmasta sama vaikutelma, joka syntyy kuulevallekin katsojalle (s. 158-159). Niinpä esimerkiksi asiapainotteisen ohjelman tekstityksessä painotetaan asiasisältöjä ja saa- tetaan muokata puhujien sananvalintoja runsaastikin. Toisaalta draaman tekstityksessä pyritään säilyttämään myös esimerkiksi murrepiirteitä, joskin valikoiden.

Sekä kirjoitustulkkien että ohjelmatekstittäjien työtapoja ohjaa tarkoitus tehdä "ääntä silmin nähtäväksi" (s. 159). Rainòn ja Laurénin sekä Pöntyksen artikkeleissa esitettyjen kuvausten perusteella näiden ammattiryhmien työtavat poikkeavat toisistaan esimerkiksi aikapaineen, kohdeyleisön ja lopullisen tekstin muodon suhteen: kirjoitustulkki tuottaa jatkuvaa tekstiä samaa tahtia kuulemansa puheen kanssa yleensä yhdelle asiakkaalle kerrallaan, kun taas ohjelmatekstittäjällä on ohjelmasta riippuen muutamasta tunnista useaan kuukauteen aikaa tuottaa tiiviitä, kahden rivin ruututekstejä varsin laajalle kohderyhmälle. Yhteistä molemmille työtavoille on kuitenkin se, että puheen verbaalista sisältöä on yhtäältä täydennettävä kontekstuaalisella tiedolla (kuka puhuu, mitä muita ääniä kuuluu) ja toisaalta tiivistettävä aikatai tilarajoitteiden vuoksi.

Lopullisen tekstin tarkoitus määrittelee vahvasti myös sitä, millä tavoin journalistit käsittelevät puhetta lehtiartikkeleissa. Lauri Haapanen analysoi artikkelissaan "Siteeraus lehtijutussa" 16 journalistin tekemien lehtihaastattelujen ja lopullisten lehtijuttujen suhdetta. Hän käyttää menetelmänä vertailevaa lingvististä tekstianalyysia sekä stimuloitua mieleenpalauttamista (stimulated recall) selvittääkseen journalistien työtapoja. Lähtökohtana Haapasella on siteerauksen "suoruuden" ideaali, johon journalismi pyrkii mutta johon ei kuitenkaan näytä olevan alalla vakiintuneita ohjeita. Haapanen osoittaakin, että journalistit muokkaavat sitaattien kieliasua lähes aina. Muokkausta ohjaavat tekeillä oleva lehtiartikkeli ja sen sisällölliset ja kerronnalliset tavoitteet: "lehtijuttu ei siis ole haastattelun kuvaus vaan dramaturgisesti itsenäinen 
ja omaehtoinen tekstikokonaisuutensa" (s. 222).

\section{Mikä on autenttista?}

Siirrettäessä puhetta tekstiksi joudutaan aina pohtimaan autenttisuuteen liittyviä kysymyksiä. Kuinka totuudenmukaisena puhe säilyy, kun se siirretään eri kanavaan? Kuinka totuudenmukaisena se pitäisi säilyttää? Ja vaikka pyrittäisiinkin mahdollisimman tarkkaan litterointiin, esimerkiksi säilyttämällä edellä mainitut epäröinnit ja väliäänet, vääristyykö lukijan tulkinta väistämättä? Liisa Tiittula ja Eero Voutilainen (s. 54-56) esittävät teoreettisessa artikkelissaan "Puhe, kirjoitus ja puheen muuttaminen kirjoitukseksi" hyödyllisen näkökulman autenttisuuskysymykseen: vaikka puheen muotoa ja sisältöä on hankalaa ellei mahdotonta muokata toisistaan erillään, voidaan kuitenkin pyrkiä kokemuksen autenttisuuteen eli siihen, että tekstimuotoon siirretyn puheen lukijalla olisi mahdollisimman samanlainen kokemus kuin alkuperäisellä kuulijalla. Tämä ajatus vaikuttaa itse asiassa lähes kaikkien teoksen artikkelien taustalla ja resonoi pitkälti käännöstieteen kanssa, alkaen Eugene Nidan (1964) dynaamisen ekvivalenssin käsitteestä.

Kysymys kirjoitetun puheen autenttisuudesta saa varsin omaleimaisen käsittelyn teoksen päättävässä Pirkko Nuolijärven ja Liisa Tiittulan artikkelissa "Puheenomaisuuden rakentaminen kaunokirjallisissa proosateksteissä", joka käsittelee kirjailijoiden ja kirjallisuuden kääntäjien työtä. Kirjoittajien aikaisempaan laajaan tutkimukseen (Tiittula \& Nuolijärvi 2013) nojaava kirjoitus esittelee haastattelu- ja tekstiaineistoja hyödyntäen kolmen kirjailijan ja kahden suomentajan työtapoja heidän kirjoittaessaan tai kääntäessään tekstiä, jossa pyritään spontaanin puheen vaikutelmaan. Vaikka osa haastatelluista kirjailijoista ja kääntäjistä kuvaa työtapojaan luovalle työlle omi- naisen impressionistisesti ("kirja valitsee kaiken", s. 265), haastatteluissa mainitaan myös tausta-aineistojen merkitys, esimerkiksi aikalaislähteiden lukeminen ja ympäristön puhetapojen tarkka kuunteleminen. Kuten kirjoittajat toteavat, tutkitut kirjailijat ja suomentajat käyttävät autenttista puhetta lähinnä raakaaineena, jota muokataan runsaasti ja joskus useaankin kertaan ennen lopullista julkaisumuotoa. Lähestymistapa on siis jokseenkin samankaltainen kuin vaikkapa journalisteilla. Artikkelin lukijalle herää kuitenkin kysymys, missä määrin kirjailijan tai suomentajan luova työ rinnastuu teoksen muissa artikkeleissa esiteltyihin toimintatapoihin, joissa on tärkeää säilyttää jonkinlainen vastaavuus mahdollisesti tunnistettavan henkilön tietyssä ajassa ja paikassa tuottamaan puheeseen. Kuten artikkelissa havainnollistetaan, kirjailijan lähtökohtana ei useinkaan ole yksittäinen todellinen lausuma vaan pikemminkin stereotyyppinen käsitys jonkin ihmisryhmän puhetavasta. Toki kirjailija ja suomentajakin pyrkivät teksteissään luomaan vaikutelman puheen autenttisuudesta, vaikka taustalla ei autenttista puhetta olisikaan.

Nuolijärven ja Tiittulan artikkelissa kiteytetään onnistuneesti havainto kirjoitetun puheen autenttisuuteen liittyvästä paradoksaalisuudesta: monesti kokemus autenttisuudesta kasvaa, mitä etäämpänä kirjoitettu puhe on autenttisesta puheesta (s. 270). Tälläkin havainnolla on pitkät perinteet käännöstieteessä, jossa lähdetekstin näennäisen tarkan seuraamisen on katsottu johtavan etäännyttäviin käännöksiin, kun taas lukijakokemuksen säilyminen mahdollisimman samanlaisena vaatii usein suuriakin kielellisiä, joskus myös sisällöllisiä, muutoksia (esim. Reiss \& Vermeer 1984). Teoksessa puheen kirjaamisen yhtäläisyyksiä kääntäjän tai tulkin työhön on hahmoteltu selkeimmin Tiittulan ja Voutilaisen sekä Rainòn ja Laurénin artikkeleissa. Jälkimmäisessä kirjoitustulk- 
kia luonnehditaan kommunikaatiosillaksi: hän toimii kolmantena osapuolena, jonka kognition kautta alkuperäinen puhe suodattuu (s. 123). Luonnehdinta pätee varmasti myös muihin teoksessa esiteltyihin toimijoihin. Teoksen lähempi kytkeminen käännöstieteeseen, jossa kääntäjän toimintaa ja erilaisten lähde- ja kohdetekstien vastaavuutta on käsitelty laajemmin, olisi saattanut antaa kiinnostavan lisänäkökulman aiheeseen.

\section{Lopuksi}

Puheesta tekstiksi on varsin kattava ja monipuolinen teos, joka tarkastelee kiinnostavalla tavalla hankaluuksia ja mahdollisuuksia, joita liittyy siihen, kun puhe siirretään tekstiksi. Teos on suunnattu varsinkin niille, jotka siirtävät työssään puhetta kirjalliseen muotoon. Aiheen teoreettinen pohjustus ja eri aloilla tehtyjen ratkaisujen tarkka esittely ja analyysi tarjoavat paitsi konkreettisia malleja ja vinkkejä toimiviksi katsotuista ratkaisuista myös pohdittavaa eri ratkaisujen eettisistä, poliittisista ja käytännön seurauksista. Teos on suunnattu myös kielen ja viestinnän opiskelijoille ja tutkijoille sekä yleensä kielestä kiinnostuneelle lukijakunnalle. Artikkelit siis pyrkivät palvelemaan niin tutkimusta kuin käytäntöä ja onnistuvatkin tavoitteessaan varsin mallikkaasti. Tutkimuskäyttöön tehtävää litterointia käsittelevää artikkelia olisi kuitenkin voinut laajentaa; tutkimusmenetelmistä kiinnostunut lukija olisi mielellään perehtynyt yksityiskohtaisempiin ja kattavampiin esimerkkeihin ja pohdintaan. On myös harmillista, että kyseisessä artikkelissa mainittu litterointikäytäntöjä esittelevä liite näyttää jääneen teoksesta pois. Se olisi ollut hyödyllinen varsinkin aiheeseen vasta perehtyvälle tutkijalle tai opiskelijalle.

Teos kuvaa monipuolisesti, miten ja miksi puhe matkaa kirjoitettuun muotoon eri aloilla. Toisaalta teokseen tuntuu osittain heijastuneen prototyyppinen käsitys "tyypillisestä" puheesta ja tekstistä - spontaanista epämuodollisesta puheesta ja hiotusta ja virallisesta tekstistä. Tiittula ja Voutilainen huomauttavatkin artikkelissaan, että epätyypillisempien aineistojen valinta tuottaisi epäilemättä toisenlaisia tuloksia puheen ja kirjoituksen suhteesta (s. 44). Tällaisia aineistoja voisivat olla esimerkiksi muodolliset puhetilanteet spontaanin puheen sijaan ja internetin keskustelufoorumit viranomais- tai lehtitekstin sijaan. Teoksessa näitä hybridi-ilmiöitä edustavat lähinnä Rainòn ja Laurénin kirjoitustulkkausta ja Pöntyksen ohjelmatekstitystä käsittelevät artikkelit, joissa tarkastellaan vain hetken näkyvissä olevaa tekstiä ja kirjoitustulkkauksen osalta myös hetkessä tuotettua tekstiä. Joka tapauksessa teos on kiinnostava kokonaisuus, joka valottaa yhteiskunnallisestikin merkittäviä puheen tekstiksi siirtämisen käytäntöjä nykyajan Suomessa.

SARI HOKKANEN etunimi.sukunimi@uta.fi

\section{Lähteet}

Bronfenbrenner, Urie 2005 [2001]: The bioecological theory of human development. - Urie Bronfenbrenner (toim.), Making human beings human. Bioecological perspectives on human development s. 3-15. Thousand Oaks, CA: Sage.

NidA, Eugene A. 1964: Toward a science of translating. With special reference to principles and procedures involved in Bible translating. Leiden: E.J. Brill.

Reiss, Katharina - Vermeer, Hans J. 1984: Grundlegung einer allgemeinen Translationstheorie. Tübingen: Niemeyer. http://doi.org/10.1515/9783111351919.

Tiittula, Liisa - Nuolijärvi, Pirkko 2013: Puheen illuusio suomenkielisessä kaunokirjallisuudessa. Suomalaisen Kirjallisuuden Seuran toimituksia 1401. Helsinki: Suomalaisen Kirjallisuuden Seura. 